Open Access

\title{
The transfer of corruptive routines from old industrial regions to innovation clusters: a blind spot in innovation studies
}

\author{
Christiane Gebhardt(10
}

Correspondence:

Christiane.Gebhardt@t-online.de

Malik Institute Switzerland,

Geltenwilenstrasse 18, CH 9001 St.

Gallen, Switzerland

\begin{abstract}
How innovation programs fail and innovation networks deviate from legal paths is a problem not yet fully understood. The complex interdependence between blockages of innovation and organizational corruption is a novel field of research in innovation studies. Equally, traditional approaches to explain opportunity-driven criminal behavior of individuals fail to explicate organizationally driven routines, and the rise of corruption despite anti-corruption campaigns remains a problem which is still unaddressed. This results in a mismatch with the increasing importance of addressing the issue of corruption. To contribute towards closing this gap, we examine, using the sociological concept of organizational deviance, the phenomenon of corruption in innovation clusters. A recent wave of corruption cases in China confirms the need for research in this area in relation to organizational role models for the transformation of mature industries and lagging regions. We discuss the potential danger of a transfer to Triple Helix-based constellations in innovation of routines found in corrupt systems that are impeding foreign direct investments and effective regional growth. The findings are based on a secondary analysis of the transformation of the Chinese coal-mining sector, a sector in which there is strong evidence of corrupt behavior and which is also a key target for politically induced transformation and modernization. The study demonstrates the importance of a consideration of organizational development in Triple Helix constellations and supports arguments in favor of good cluster governance in Triple Helix-based regional innovation systems.
\end{abstract}


摘 要: 创新项目如何失败、创新网络怎样偏离法律路径是个尚未完全理解的问 题。创新障碍与组织腐败之间复杂的相互依存关系是创新研究的新兴领域。同 样,解释机会驱动的个人犯罪行为的传统方法也不能解释组织驱动的惯例。尽管 反腐败运动兴起,这仍然是一个尚未解决的问题,导致与处理腐败问题日益重要性 之间的不相配。为了弥补这个缺失, 我们利用组织偏差这一社会学概念探讨创新 集群中的腐败现象。中国最近的一波腐败案件证实了需要这个研究领域探索成 熟产业和落后地区转型的组织角色模式。我们讨论在遏制外国直接投资和有效 区域增长的腐败体系中发现的惯例的创新中,转移到基于三螺旋星座的潜在危 险。研究结果基于对中国煤矿部门转型的二次分析,这是一个有强有力的腐败行 为证据的部门，也是政治转型和现代化建设的关键目标。研究表明在三螺旋星座 中考虑组织发展的重要性,并支持在基于三螺旋的区域创新体系中有利于良好的 集群治理的论据。

关键词: 腐败、创新政策、反腐败、中国、煤矿业、腐败体系、分权化、快速发 展的经济体、良好的集群治理,基于三螺旋的区域创新体系、组织偏差、转 型、现代化 
Résumé: Comment les programmes d'innovation échouent et comment les réseaux d'innovation dévient de la voie légale est un problème non encore élucidé. L'interdépendance complexe entre les blocages à l'innovation et la corruption organisationnelle est un champ de recherche novateur dans les études sur l'innovation. De même, les approches traditionnelles pour expliquer les comportements criminels opportunistes des individus ont échoué à expliquer les habitudes organisationnelles et la montée de la corruption en dépit des campagnes anticorruption. II en résulte un décalage, étant donné l'importance croissante de la lutte anticorruption. En vue de contribuer à combler ce vide, nous examinons le phénomène de la corruption dans les pôles d'innovation en utilisant le concept sociologique de déviance organisationnelle. Une récente vague de cas de corruption en Chine confirme le besoin de recherche dans ce domaine en relation avec les modèles organisationnels pour la transformation des industries traditionnelles et des régions déshéritées. L'auteur analyse le danger potentiel que représente le transfert de procédés existant dans les systèmes corrompus vers les constellations d'innovation de la Triple Hélice et qui handicape une croissance régionale efficace et des investissements directs étrangers. L'étude est basée sur l'analyse secondaire de la transformation du secteur chinois d'extraction du charbon, un secteur où des preuves tangibles de comportements corrompus existent et dont la transformation et la modernisation sont politiquement encouragées. L'étude démontre l'importance d'une prise en compte du développement organisationnel dans les constellations de Triple Hélice et plaide pour une meilleure gouvernance des pôles et des systèmes régionaux d'innovation basés sur la Triple Hélice.

Mots-clés: corruption, politique d'innovation, anti-corruption, Chine, secteur du charbon, systèmes corrompus, décentralisation, économies à développement accéléré, bonne gouvernance, systèmes régionaux d'innovation basés sur la Triple Hélice, déviance organisationnelle, transformation, modernisation 
Resumo: Como os programas de inovação falham e as redes de inovação se desviam dos caminhos legais é um problema ainda não totalmente compreendido. A interdependência complexa entre bloqueios da inovação e corrupção organizacional é um novo campo de pesquisa em estudos de inovação. Do mesmo modo, as abordagens tradicionais para explicar as oportunidades dirigidas para um comportamento criminoso de indivíduos falham em explicar rotinas dirigidas para organizadas e o aumento da corrupção, apesar das campanhas anticorrupção, o que continua sendo um problema ainda não abordado. Isso resulta em uma incompatibilidade com a crescente importância de abordar a questão da corrupção. Para contribuir para o fechamento dessa lacuna, nós examinamos, usando o conceito sociológico de desvio organizacional, o fenômeno da corrupção em clusters de inovação. Uma recente onda de casos de corrupção na China confirma a necessidade de pesquisa nesta área em relação ao papel dos modelos modelos para a transformação de indústrias maduras e regiões em atraso. Nós discutimos o perigo potencial de uma transferência para constelações de inovação baseadas na Hélice Tríplice de rotinas encontradas em sistemas corruptos que impedem investimentos diretos estrangeiros e um crescimento regional efetivo. As descobertas são baseadas em uma análise secundária da transformação do setor chinês de mineração de carvão, um setor em que há evidências fortes de comportamento corrupto e que também é um alvo-chave para a transformação e modernização induzidas politicamente. O estudo demonstra a importância de uma consideração do desenvolvimento organizacional nas constelações da Hélice Triplice e apoia argumentos a favor da boa governança de cluster em sistemas de inovação regional baseados na Hélice Tríplice.

Palavras-chave: corrupção, política de inovação, anticorrupção, China, setor de mineração de carvão, sistemas corruptos, descentralização, economias em rápido crescimento, boa governança em cluster, sistemas regionais de inovação baseados na Hélice Tríplice, desvio organizacional, transformação, modernização 
Аннотация: Проблемы, возникающие вследствие провала инновационных программ и отклонения инновационных экосистем от законных путей развития, являются недостаточно изученными. Сложная взаимозависимость между торможением инноваций и организационной коррупцией является новой сферой для изучения в инновационных исследованиях. Кроме того, традиционные подходы к объяснению движимого будущими перспективами криминального поведения индивидов неспособны объяснить принятые в корпорациях практики и рост коррупции несмотря на антикоррупционные кампании, что продолжает являться недостаточно исследованной проблемой. Это приводит к нестыковке с возрастающим интересом к вопросам, связанным с антикоррупционной борьбой. Для того, чтобы сделать вклад в данный информационный пробел, мы исследовали феномен коррупции в инновационных кластерах при помощи социологического подхода к организационным сдвигам. Недавняя волна коррупционных скандалов в Китае подтверждает необходимость подобного исследования во взаимосвязи с организационными ролевыми моделями для трансформации зрелых отраслей и отстающих регионов. Мы обсудили потенциальный риск переноса в инновационные трехспиральные группировки практик, обнаруженных в коррупционных системах, которые затрудняют приток прямых иностранных инвестиций и эффективный региональный рост. Выводы основаны на вторичном анализе трансформации китайского угледобывающего сектора, в котором подтверждены случаи серьезных коррупционных нарушений и который также является ключевой сферой проведения трансформации и модернизации, инициированных властью. Исследование указывает на важность планирования с учетом специфики организационного развития в различных конформациях Тройных спиралей и поддерживает доводы в пользу надлежащего управления кластером в Трехспиральных региональных инновационных системах.

Ключевые слова: Коррупция, инновационная политика, антикоррупционный, Китай, угледобывающий сектор, коррупционные системы, децентрализация, быстрорастущие экономики, надлежащее управление кластером, Тройная спираль, основанная на региональной инновационной системе, организационный сдвиг, трансформация, модернизация. 
Resumen: Como fracasan los programas de innovación y como se desvían de la vía legal las redes de innovación son problemas que carecen de una respuesta completa. La compleja interdependencia entre los bloques de innovación y la corrupción organizacional es un campo novedoso de investigación en estudios de la innovación. Del mismo modo, los enfoques tradicionales para explicar el comportamiento criminal no explican el aumento de la corrupción de rutinas organizacionales. Esto sugiere la creciente importancia del tema de la corrupción. Para contribuir a cerrar esta brecha se examina, utilizando el concepto sociológico de desviación organizacional, el fenómeno de la corrupción en los bloques de innovación. Una reciente ola de casos de corrupción en China confirma la necesidad de investigación en esta área en relación con los modelos organizativos a seguir para la transformación tanto de las industrias maduras como de las regiones rezagadas. Discutimos el peligro potencial de una transferencia de rutinas desde sistemas corruptos hacia las constelaciones basadas en Triple Hélice. Esta transferencia podría obstaculizar las inversiones extranjeras directas y el crecimiento regional. Los resultados se basan en un análisis secundario de la transformación del sector chino de la minería del carbón, un sector en el que hay fuertes indicios de comportamiento corrupto y que también es un sector clave para la transformación y la modernización inducidas políticamente. El estudio demuestra la importancia del desarrollo organizacional en las constelaciones de la Triple Hélice, y apoya los argumentos a favor de una buena gobernanza de bloques en sistemas de innovación regional basados en la Triple Hélice.

Palabras clave: China, Triple Hélice, Sistemas de innovación regional, sistemas de corrupción, modernización, decentralización, economías de crecimiento acelerado, ilegalidad útil, sector minero del carbón

Keywords: Corruption, Innovation policy, Anti-corruption, China, Coal-mining sector, Corrupt systems, Decentralization, Fast-growing economies, Good cluster governance, Triple Helix-based regional innovation systems, Organizational deviance, Transformation, Modernization

\section{Multilingual abstract}

Please see Additional file 1 for translation of the abstract into Arabic.

\section{Introduction: addressing a blind spot of organizational deviance in innovation policy}

How innovation programs fail and innovation networks deviate from legal paths is a problem not yet fully understood. The complex interdependence between blockages of innovation and organizational corruption is a novel field of research in innovation studies. However, a recent wave of corruption show trials in China and rising public awareness of government intervention to stop corruption confirm that the subject of corruption is increasingly conceived as a major obstruction to further investments in innovation. In fact, we are dealing with two different types of corruption here. Reflecting on the relation of management to morality, Pohlmann pointed out 'that managers use the means of corruption (e.g., bribes), for instance in emerging markets BRIC (Brazil, Russia, India, China) countries, to acquire contracts by bribing administration or procurement officers or to protect the company's employees from the imminent danger of local mafia clans' (Pohlmann in: Klinkhammer 2013: 170, on the Siemens bribery case). Though such active corruption might be against the law (that is, criminal behavior), Pohlmann argued that the managers' actions are in many cases related to the corporate value 
system and what seems to be 'best' for the company; that is to say, in criminological terms, they are corporate, or organizational crimes ${ }^{1}$. In marked contrast, corruption which is occupational crime cannot be linked to any organizational values. If anything, the action's meaning usually allows for an easy discrimination of a criminal value system (e.g., an employee's act of embezzlement to the detriment of his employer) (Klinkhammer 2013: 194). The same line of reasoning applies to the embezzlement of dedicated innovation funds in order to finance other things, e.g., new industries, entrepreneurs, education, culture and charity projects, social welfare, and public buildings. Can the infringement of intellectual property rights, patents, and other industrial rights for the benefit of local companies and the national economy be an accepted form of technology transfer? Is academic entrepreneurship and making money in academia against the law if there is no law to regulate it? This is an illegal behavior but it is not necessarily a private gain or money laundering of individuals and clans. In this grey zone, behaviour relies on laws and regulations, the organizational culture, and on societal values. What can be welfare on local or provincial community level might violate law or inhibit innovation policy programs and transformation policies of the central government (Chen et al. 2011, Granovetter 2007 on social construction and the subtility of corruptive behavior and different forms of corruption). A third category can be used for China, where a cognitive normality to intertwine both dimensions still lingers: organizational aspects of networking in industrial clusters meet with a culture of networking of family and clans (not related to organized crimes and felony). Rule of man rather than rule of law prevails and gets into conflict with anti-corruption issues.

We examine the problem in the energy sector. International studies suggest that

...the energy sector per se is a prime target for, and source of corruption, in part because of the time-sensitive nature of energy resources that involve a timely application for permits and licenses for exploration, development of wells and mines, and extraction of minerals and fuels. Players will be the same over a long time. In the energy sector the opportunity of generating considerable economic rents from energy extraction, transformation and use are high, as well as the need for large capital investments and a central role of Government agencies to oversee virtually all aspects of the energy sector - whether privatized or not. (Ruth 2002)

In China, the importance of the energy sector for the growing economy, the sociopolitical context within which extraction, transformation, and use occur, the number of individuals participating in decisionmaking, and the cultural environment within which decisions are made bear a striking structural similarity to large-scale innovation projects. A lack of transparency in decision making, as well as a lack of effectiveness of legal systems, which may cause abuse of power by decision makers and the coincidence of a politically induced sectorial transformation that 'rocks the boat', makes the energy sector a rich empirical field for studying organizational deviance and the transfer of corrupt routines.

Importantly, in this organizational study, corruption is no longer classified as opportunity-driven criminal behavior of individuals but, rather, as a "normal" individual adaptation to organizational routines and a "business as usual" routine (Anand et al. 2004). 
This approach gives us room for systematic empirical research on illegal, proorganizational cluster behavior. Discussing the phenomenon of corruption in the Anglo-American sociological tradition of organizational deviance (see Ashforth and Anand 2003; Ashford et al. 2008; Pinto et al. 2008 on the concept), we use the concept to analyze the value proposition of the Triple Helix model ${ }^{2}$ with regard to cultural change and cluster governance ${ }^{3}$. We transfer the concept of organizational deviance to cluster organizations that are characterized by formal and informal networking of different institutions with the joint objective "...to innovate, transform and upgrade their industrial and regional context in a joint effort" (Etzkowitz and Leydesdorff 2000; Cooke and Leydesdorff 2006). We examine the transfer of belief systems in a period of transformation in China which is characterized by a policy "to merge, reform and recombine the institutional landscape for a shift from quantity to quality" (Zhou and Etzkowitz 2012; on universities in the Triple Helix in China). Etzkowitz stated that:

...communications and negotiations between institutional partners in innovation clusters based on the Triple Helix model generate an overlay that increasingly reorganizes the underlying arrangements and triggers a new culture of consensual collaboration in a way that the institutional layer and the communication culture can be considered a retention mechanism of a developing system. (Etzkowitz, 2002)

Alas, the question then arises: can it be the case that what appears to be a good model for spinning off innovative development might also make it an easy prey for corrupt systems in the transition phase from the old networks to a new order of innovation cluster? It is hard to the draw a line between good (innovative) and bad (corrupt) relationships. This functional approach towards innovation in societies, which is inherent in the Triple Helix model, works with a wider societal perspective of a Quadruple Helix and foresees an active role of policy. 'This implies that policy needs to design the framework conditions in a society [...].'(Carayannis and Campbell 2009; Campbell et al. 2015; Carayannis et al. 2017: 42 for the Quadruple Helix approach). Society in this present study is represented by the media, investigative journalists, and experts outside the innovation clusters and mature clusters, as well as researchers and consultants who are not part of the technological or local community.

We assume that the transition from traditional regional networking in old clusters to networking towards innovation must rely primarily on the shift from the rent-seeking of a closed system to a culture of open and disruptive innovation. Applying the concept of organizational deviance to innovation networks will shed new light on how innovation clusters can be kept on track by cluster governance in order to safeguard the innovation path for which these innovation clusters were given financial investments.

We assume that, alongside the technological knowledge transfer and the emergence of Triple Helix behavioral patterns and mind sets, traditional values and undesirable, corrupt behavior transfer from old, corrupt networks to new settings of high technology clusters, and thus diminish the positive attributes of innovation such as the introduction of new, innovative players as well as societal and economic effects such as growth, transparency, participation and attractiveness of regions and industries for foreign investments and talents. We venture the thesis that the transition from lagging regions and mature industries to innovative settings has to be managed with an eye to the organizational 
context and to underlying, informal behavioral patterns. Furthermore, we consider that good cluster governance prevents co-optation of new innovation clusters by corrupt routines.

The paper adds a new perspective of organizational development and cluster governance to studies in innovation and offers an explanation for the embezzlement of innovation funds.

The study addresses the following research questions.

1. What are the characteristics of organizational deviance in corruptive systems?

2. Can new forms of innovation policies, and concepts such as Triple Helix-based regional innovation systems, bring about changing interpretative schemes of cultural traditions and disrupt corrupt patterns?-Or do they facilitate the movement of corrupt systems?

3. What are the main features of effective anti-corruption schemes in the context of this consideration?-And, further, what must be changed to prevent the transfer of corrupt behavior and encourage the installation of good cluster governance to make innovation clusters effective?

We start with a discussion of the key concept of organizational deviance for analyzing corrupt systems in the context of the innovation-based modernization and transformation of the fast-growing and changing Chinese economy and society. The characteristics of corrupt systems are illustrated by a secondary analysis of interviews carried out in the context of the transformation of the Chinese coal mining industry, a mature industry based on long-lived regional networks. Coal mining is a sector that ranks high on the corruption perception index of Transparency International ${ }^{4}$ and is a key target for politically induced transformation.

This is followed by details of the research design, explaining the operationalization of the concept of organizational deviance for our research and providing details of the Quadruple Helix interview sample for the study. We then discuss the findings: these reveal the characteristics of corrupt systems in the coal mining industry and we discuss their transferability to innovation cluster settings, based on the interviews and the secondary analysis of the coal mining study and on interviews carried out by the author in Chinese institutions related to innovation. This also includes the discussion of the interdependency of Chinese innovation policy, cluster organization, and prevalence of belief systems that form the culturally specific routines of corrupt systems. We introduce lack of regulations and an open code of conduct for the implementation of innovation, lack of cluster governance, insecurity triggered by rapid change, cluster organization per se, and decentralization policies as new explanatory variables for the movement of corrupt systems. The paper concludes with a recommendation for an anti-corruption scheme and cluster governance for the Triple Helix model.

\section{Literature review: the transfer of corruptive routines from old industrial regions to innovation clusters-a blind spot in innovation studies}

In innovation policy, corruption is deemed to have a negative impact on the effective use of science and technological investments, and to contribute to a diminished legitimacy of government and the destabilization of democratic institutions, and further 
distortions in public spending. This phenomenon constitutes an organizational and interdisciplinary problem that is neither sufficiently addressed by statistics in the corruption indexes nor compiled by anti-corruption compliance schemes deriving from law schools (see overviews of traditional approaches in Behringer 2015; Lambsdorff 2007; Roth 2014). Similarly, selective actions which punish individuals for corrupt behavior lack the organizational dimension of the phenomenon (Yuanyuan and Pohlmann 2016) for the situation in China; Pohlmann et al. 2016).

As indicated above, the literature on innovation policy and innovation clusters generally neglects the fact that corruption travels as a stowaway when old industrial regions are being transformed, with the implementation of innovation policy and science and technology spendings, into regional innovation systems (Boekholt 2010; Breznitz and Murphree 2011; Chaminade and Edquist 2010; Edquist 1997; Gu and Lundvall 2006; Smits et al. 2010). Regional innovation systems are made of different institutions. However, networking of organizations and networking of individuals are relevant characteristics of these systems. Granovetter argued "[...] that most behavior is closely embedded in networks of interpersonal relations and that such an argument avoids the extremes of under- and oversocialized views of human actions." (Granovetter 1985: 504). Based on Granovetter's work, Grabher (1993) studied industrial transformation of lagging regions with an emphasis on the blockages of the transition, but gave no advice regarding the organization of the transformation process. Grabher's work on embedded firms and networking relationships in the coal mining gives reason for concern that long-standing personal ties lead to cognitive "lock-in" and become a vicious circle that blocks innovation in the long term (Grabher 1993; on structural change of the coal mining sector in the Ruhr region of Germany; Granovetter 1985 on the theoretical concept of embeddedness and how behavior and institutions are affected by social behavior). Saxenian showed that the export of US-based innovation concepts and entrepreneurial belief systems to new locations by a few technically skilled entrepreneurs resulted in changes for the better to the existing collective mindset (Saxenian 2006). However, Saxenian left room for speculation about how the cognitive transition can be managed, or be supported, by innovation policy.

It appears that the management of the transition phase and the repurposing of social networks must be critical success factors for innovation and modernization. Indeed, members of innovation clusters must necessarily enter into conflict with both the established procedures and the formal institutional routines and rules that are inadequate for innovative disruption. In the absence of governance and a stable cognitive reference model for the transition, innovation clusters are likely to fall back on established, trust-based informal rules (Pohlmann 2008).

In this context, China is a highly relevant case for illustrating the interdependency of innovation policy, innovation clusters, and the transition from an old to a new order and for studying the persistence or movement of collective belief systems. Since 2013, the anti-corruption campaigns of the Chinese government have addressed the problem of corruption with show cases and draconian punishments of individuals, in order to regain the trust of those making investments (Lu 2000; Gong 1997). However, the likelihood of individual detection depends on the robustness of the system of corruption, on organizational and cultural aspects, and the sense-making in the system-that is, on "interlocking routines, inter-subjectivity of mutually reinforcing interpretations and the 
movement back and forth between these two forms by means of continuous communication" (Weick 1995: 170).

Many authors consider government corruption as a major obstacle to innovation in China (Anderlini 2010; Suttmeier 1985; Otter and Weber 2015). In her work, Zhou discussed Chinese corruption as a long-term obstacle to innovation (Zhou 2014; see also Balzer and Askonas 2016; Tagscherer et al. 2012). However, Zhou and many other authors never venture beyond the legal concept of corruption and discuss criminal misbehavior of individuals - for example, bribery by, and personal gain for, individuals in business and administration. Other authors have concentrated on areas such as mafia corruption, high-level government corruption, and discussion of how anti-corruption campaigns are being used to target political rivals (Broadhurst and Wang 2014; Wang 2014).

In our view, decisions at the level of the individual are not made in a vacuum but are embedded in society (Gonin et al. 2012). In this study, the phenomenon of "corruption" is regarded as organizational deviant behavior that persists or is transported to new regional innovation systems via the investment of political elites and the export of belief systems, organizational routines and the absence of an open dialogue on the cultural change dimension. In our study, we follow Polischuk's approach that the probability of corruptive systems is augmented by a high growth dynamic of the economy and when it occurs in a transition phase, because both indicate cultural change on a large scale and the mismatch of belief systems related to a shift from the old to a new order (Polishchuk 2009).

The hypothesis is proposed that high-level concepts and innovation programs, which rely on regional innovation systems, are in danger of becoming co-opted by existing informal corruptive systems, with funds possibly being diverted. The transfer of behavioral patterns or routines of established elites in the political-industrial complex, from mature industries to innovative settings and industries, is likely. Thus, technocracy-that is, ignorance of the social dimension of innovation and reliance on hidden values-may lead to co-optation or deviation of programs. Accordingly, concepts of effective anti-corruption compliance must both address the cultural change that innovation clusters generate and govern the implementation of concepts, especially in decentralized settings in fast-changing economies.

\section{Routine corruption in the Chinese context and the concept of organizational deviance}

"Corruption" remains a multifaceted concept and covers a broad range of human actions. Behind the term, there is an agglomeration of aspects and definitions (Staffhorst 2010: 26). In the Western tradition, the public management view of corruption is clear-cut: systemic corruption, in the form of graft and patronage and the inefficiencies that accompany it, spurred the nineteenth century reforms in Europe and North America which led to the creation of the modern bureaucratic state. In the light of Weberian theory, corruption opposes the bureaucratic values of equity, efficiency, transparency, and accountability. These criteria represent a somewhat universal code of conduct for public administrations across the globe. The World Bank defines corruption simply as the abuse of public office for private gain: "Public office is abused for private gain when an official accepts, solicits, or 
extorts a bribe" (World Bank 1997: 8). Heberer, for example, hinted at offending public interests, offending morals aspects and the abuse of power on behalf of any person (Heberer 1991: 16). This provides an indication of the character of corruption with regard to outsiders; that is, corruption is something that is not on behalf of the entire population or the peer group, and does not accommodate the generally-accepted moral values. We therefore need to differentiate between corrupt associations of high-level politicians dealing with organized business interest and corruption that occurs in the routine administration of public programs (Della Porta and RoseAckerman 2002: 12).

Routine corruption takes on a systemic character and is characterized by an experienced process of corruption either with the help of the state or even to support it (Jansen 2005). It is part of the day-to-day operation of government and therefore a "normal" activity when business or academia is dealing with officials of the state. Part of it is concerned, for example, with paying officials and receiving benefits in the absence of imposed restrictive conditions, or to avoid the "formal process" and obtain benefits faster (Della Porta and Rose-Ackerman 2002: 13).

Corruption is seen as a problem in innovation because it impedes the selection of best solutions and talents, hampers foreign involvement, and leads to an unequal distribution of wealth. There is the danger that technological, economic, and societal goals of innovation funding cannot be met. Since the end of the 1980s international organizations such as the OECD, the International Labour Organization and the UN (United Nations) have formulated moral guidelines for business (Behringer, 2015; OECD 2010; Reindl, 2014). In addition, the Transparency International Index (TII) shows that awareness of corruption is rising (TII 2015); this has also been triggered by (social) media covering the recent series of purges in China (Yuanyuan and Pohlmann 2016; Martin 2016). However, because of geographical limitations, international and national laws do not cover many of the international business activities of firms, while different environments expose enterprises to specific societal and economic interests. Thus, enterprises give themselves rules in order to provide more security for decision-making and interaction, and to find solutions in handling conflicting interests. This has culminated in concepts such as Corporate Governance Codes, Corporate Compliance, Corporate Social Responsibility and Corporate Citizenship, and many others.

However, in a cultural perspective and for China, it is hard to define what is (il-)legal or "wrong" in a political economy having imprecise but complex laws, intricate investment schemes, the primacy of politics and strong "informal rules," and a culture of pervasive gift-giving, an ambivalent attitude towards private wealth-and the dominance of guanxi or personal networking (Redding 1993). Formal rules remain in place, but they are superseded by informal rules (Gray 1991). Even if corruption is measured regularly (see, for example, the corruption perceptions index, the global corruption barometer and the bribe payers index), there is no scale of corruption that makes it possible to measure it with complete accuracy (Rohwer 2009; TII 2015).

A systems approach such as organizational deviance adds an explanatory element to account for corrupt systems and the correlation between innovation policies and the break-up or prevalence of clientelism and cultural patterns in established industrial regions and mature industries. In his work, Klinkhammer underlined the organizational development perspective in the transition process from an old to a new order, linking 
the concept of organizational deviance to corrupt systems (Klinkhammer 2013). Using this organizational perspective, the present paper addresses the research gap between criminological- and regulatory-based concepts used by the World Bank, and other supervisory bodies, to detect and prevent corrupt behavior.

Luhmann's early work (Luhmann 1964) about the operation and consequences of formal organizations merged into the concept of organizational deviance (Klinkhammer 2013; Pohlmann 2008 for the corporate sector; and Ashforth and Anand 2003; Ashford et al. 2008 and Pinto et al. 2008 on the concept). These authors provide a new, reframing systemic concept regarding morality and organizational deviance which can be applied to Triple Helix constellations. Luhmann defined organizations in modern society as "social interaction systems, in which the factual action is ordered by a structure of particular formal expectations" (Luhmann 1964: 29). Social systems therefore define a border between themselves and their environment. For the purposes of adaption to the environment, one strategy of the system might be to change itself (Luhmann 1964: 123). At the same time, the interaction will create an inner arrangement through the repetition of communication that will be relatively stable with regard to changes in the environment, which means it acts in an autopoietic manner-that is, capable of self-maintaining and self-regulating itself. In an organization, formal expectations become important: these formal expectations, which help to protect the organization from outside influence, regulate the actions of the members of the organization. At the same time, Luhmann stressed that "a fully formalized system would not be able to survive" (Luhmann 1964: 27). Similarly, Mayntz specified that the rigidity of an administration modeled on the Weberian bureaucratic stereotype can only run standard operations in a repetitive mode but fails when coping with new, undefined challenges and new tasks and active roles (Mayntz 1978: 45) - for example, managing innovation clusters, changing teaching universities into entrepreneurial universities and facilitating structural change in lagging regions. Therefore, "each and every complex organization with a rational, consistent norm structure has to resort to illegal behavior - at least to some extent - to 'keep the organization going' ..." (Cressey 1959 in: Klinkhammer 2013: 194).

"Illegality" and "deviance" have their origins in the conflict between the formal and informal rules of an organization and the often conflicting requirements of the environment in which the organization has to operate. People act accordingly and decisions are made from the routines, for future reference. Formal expectations will be either followed or ignored, and each individual, knowing that they must choose between these two possibilities, will assign actual meaning to formal expectations as the genuine basis of decisions. Informal rules conveyed by communication and cultural traditions lack the cognitive quality and transparency of formal rules and appear to be more hidden and robust. Formal and informal rules not only determine present behavior but also, and even more so, will do so for the future and thus provide a perspective of stability and security. High level innovation policies and changing paradigms in the transition from mature networks to high-tech Triple Helix-based regional innovation systems can disturb established routines and very often do not provide for new ones. In the absence of new formal routines for cooperation, innovation clusters may fall back on existing, informal routines when players perceive their situation as insecure and constantly changing. The need is to build a critical mass, in which the movement of a few cluster 
members gives rise to new collective behavior. The provision of role models for cluster networking is the tipping point for change to the better.

\section{Research design and data collection}

When gathering data on corruption and deviance, there is no guarantee that the respondents will want to talk about their behavior to outsiders or give evidence of that behavior in surveys. We therefore need to identify methods which avoid the social desirability of investigative schemes that address cultural patterns. In other words, we must avoid the tendency of interviewees to answer in a way that will be viewed favorably by others (Esser 1986; Venard 2009). Lancaster and Montinola emphasized that "[a] key challenge in an empirical survey about corruption is to obtain honest answers from the respondents" (Lancaster and Montinola 2001: cited by Venard 2009: 66).

On this basis, secondary data, available from a study by Martin on accidents in the Chinese coal mining industry and on the nationalization/ centralization of local coal mines in several provinces (Martin 2016, 2015), were used. Many statements in the original interviews point to the topic of corruption. This was an unintended effect and provided a rich empirical pool for a corruption study that avoids the social desirability problem in corruption studies. Martin presented his research in the master lab in innovation management at the University of Heidelberg in 2016, run by the present author. Raw data from qualitative interviews and additional material from this $\mathrm{PhD}$ study were used with the kind permission of the author (Martin 2016) to address the new problem of the likelihood of the transmission of organizational deviant behavior to innovation clusters.

There are four typical situations in which a high level of insecurity may cause a regression into informal behavior. These situations were identified by researchers in organizational deviance (Ashforth and Anand 2003; Pinto et al. 2008; Campbell and Göritz 2014 in: Pohlmann et al. 2016). The typical situations operationalize the concept of organizational deviance for this study and confirm the research design.

(1)Performance pressure caused by competition: ambitious goals set by the central government and provincial benchmarking are based on benchmarking figures. Ambitious, political targets are set in a top-down style: the way to achieve these targets is not defined and performance evaluation is not transparent (interviews carried out by Gebhardt in 2015, CASTED (Chinese Agency for Science, Technology, Education and Development; Sino-German Platform on the need for organization and operation mechanism for securing strategy implementation-see https:// www.bmbf.de/pub/China_Strategy_Longversion.pdf).

(2)Hierarchical pressure. As a general rule, organizational players high up in a hierarchy define informal expectations or tolerate deviant practices (see Ashforth and Anand 2003: 7, 689; Anand et al. 2004; Palmer 2012: 174; Campbell and Göritz 2014). Hierarchical pressure can be found in the intergovernmental setting (central government, provincial and local administration); it is also a prominent feature in the organizational setting of cluster members. Within Chinese institutions, members of the organization are loyal to an inter-organizational well-connected president or head of the organization (Gebhardt, interviews in Chinese firms and universities, 2015). The Chinese Communist Party (CCP) has a chain of command 
(central-province-local party members): there is a primacy of politics. Also, (hierarchy of) social status and face keeping plays a role in the quid pro quo exchange of "gift" giving and granting favors (e.g., being from lower status makes it easier to accept a bribe from someone with a higher status in society). Conversely, the behavior may be considered an offense. Intermediaries or a go-between the different actors can help to balance the discrepancy of status and information (Granovetter 2007: 159); such intermediaries (individuals) are common in new innovation clusters; long established corruptive systems do not rely upon them (interviews carried out by Gebhardt in consulting firms in China in 2015).

(3) A shared framework for interpretation of insights in their own reality that add rationality and legitimatization to actions as a framework for future actions (Ashforth and Anand 2003: 17): The coal mining sector has experienced a dramatic change in policy: in the last decade, industrial transformation, closures, and centralization became the focus of policy after a long period of decentralization. This shift disturbed the tit-for-tat bargaining model at local level and added to the intergovernmental or vertical power networks (levels: centre, province and local) (Gebhardt, interviews with Chinese consultants for foreign companies in china with a focus on old industrial clusters related to textile industry in 2016). The shared framework for interpretation disintegrates.

(4) Socialization according to unwritten rules (Ashforth and Anand 2003) that accompanies building of trust in organizations (Luhmann 1964: 311, in Pohlmann et al. 2016). There are guanxi networks in local communities and sectorial regional clusters involving members of local government, firms, and educational or teaching institutions. In addition, personal relationships of cadres can be found as a result of the typical career paths of a highly connected elite. In China, socialization takes place in networks.

About 90 interviews according to the Quadruple Helix model were carried out in China, in the Chinese language, by a foreign interviewer. Data were obtained from local and provincial owners of coal mines and plants in Shanxi, Shaanxi and Guizhou as well as from office holders in regional and municipal administration, consultants, experts on the coal industry in China at the national level, and from investigative journalists who covered coal mine accidents (Martin 2016: 49, 172; see Table 1). This data pool was enriched with 13 unstructured interviews carried out by the author in the context of strategy consulting, in the Teda Tjianjin High Tech Zone, in the Chinese Agency for Science, Technology, Education and Development (CASTED) and the State

Table 1 Interviews according to the Quadruple Helix Matrix

\begin{tabular}{|c|c|c|c|c|}
\hline & University & Industry & Government & Society \\
\hline $\begin{array}{l}\text { Mature clusters } \\
\text { (coal mining) Shanxi, } \\
\text { Shaanxi, Guizhou }\end{array}$ & $\begin{array}{l}\text { - Researchers in } \\
\text { coal mining } \\
\text { - Local training } \\
\text { institutions } \\
\text { (vocational) }\end{array}$ & $\begin{array}{l}\text { - Owners of local } \\
\text { coal mines } \\
\text { - SOE Managers }\end{array}$ & $\begin{array}{l}\text { - Party members, } \\
\text { local, provincial, } \\
\text { central }\end{array}$ & $\begin{array}{l}\text { - Investigative } \\
\text { journalists } \\
\text { - Industry experts } \\
\text { - Consultants }\end{array}$ \\
\hline $\begin{array}{l}\text { Innovative clusters } \\
\text { (high tech) Beijing, } \\
\text { Shanghai, Tjianjin }\end{array}$ & $\begin{array}{l}\text { - Business schools } \\
\text { (Tsinghua) } \\
\text { - Universities } \\
\text { (IMAU, Tongji) } \\
\text { - Students/researchers/ } \\
\text { faculty members }\end{array}$ & $\begin{array}{l}\text { - Chinese managers } \\
\text { in foreign firms } \\
\text { - Chinese high } \\
\text { technology firms } \\
\text { (f.e. Huawei Shenzhen) }\end{array}$ & $\begin{array}{l}\text { - High technology } \\
\text { zone management } \\
\text { (Teda) } \\
\text { - CASTED }\end{array}$ & $\begin{array}{l}\text { - Intermediaries } \\
\text { - SAFEA } \\
\text { - Consultants }\end{array}$ \\
\hline
\end{tabular}

Source: Carayannis et al. 2017; Carayannis and Campbell 2009 
Administration of Foreign Experts Affairs (SAFEA), with Chinese Managers employed in a Beijing management consulting firm and with researchers at Tsinghua, and Inner Mongolia Agricultural University (IMAU).

These interviews were carried out in the absence of a specific scientific interest in corruption. The secondary analysis of the Martin (2016) study serves as the reconstruction of social processes or situations from which an explanation of the nature of corrupt systems in China can be derived (for details of the method, see Gläser and Laudel 2010: 13). The aim was to uncover mechanisms which would explain certain processes in the context of interaction routines and organizational constellations (Kruse 2015). Qualitative interviews or "narrative traps" (so-called because interviewees revealed these informal routines in an unintended way) provided the means for analyzing the perceptions regarding behavior, personal opinions, thoughts, feelings, and explanations (Helfferich 2009: 91) on typical episodes, and the circumstances which exist when administration, academia and business meet on the turf of innovation and transformation.

\section{Findings}

\section{Turbulent times of rapid growth}

China's economic growth has shed new light on the domestic energy supply, and the central government is seeking to modernize and transform coal mining clusters in many provinces to meet the demands for energy of the growing economy. Nationalization/centralization, or closing of coal mines, and spectacular show trials in corruption, have accompanied this modernization policy and form the basis for the intricate involvement of party elite, local mine holders, and teaching universities in complex corruption schemes.

Moreover, the situation has led to the flight of capital, in which funds have traveled from old clusters to new high technology zones in China and abroad (Martin 2016; Pohlmann et al. 2016; interviews carried out by Gebhardt in 2016). However, despite the substantial challenges China is facing, the functioning of the political-businessand-administration nexus is important for public tendering, obtaining construction and employment permits, land use and other administrative authorizations. Transparency and reliability of this process becomes a crucial and internationally visible regulatory framework for building up trust and securing investments from Chinese and foreign investors unfamiliar with the political and commercial environments. Formal rules are also needed to allow for matching funding of industrial R\&D (Research and Development), economic exploitation of intellectual property rights on legal terms, entrepreneurial activities of university faculty members, and entrepreneurial governmental S\&T (Science and Technology) investments as well as joint university-industry research projects and professionalization of business angels-all of which are features of Triple Helix-based innovation clusters.

Economically, the Chinese path of modernization appeared to pay off for the population; an average GDP growth of 10\% during the period 1978-2006 spoke for itself. However, with regard to the inequality of income, China is also at the forefront and reached a warning level: China's Gini-coefficient increased from 40.74 points in 1993 to 47.25 points in 2004 (Wang and Woo 2011: 2 2016: 46,5 points; statista.com accessed 09.06.2017 ), and China's ratio of the incomes of the richest $20 \%$ to those of the poorest 
$20 \%$ is the highest in Asia. The report by Wang and Woo (2011) confirmed a large amount of "hidden income" in the upper class: the wealthiest $20 \%$ of the urban population accounted for more than $80 \%$ of all hidden income.

In brief, the following seven features give rise to insecurity and fragmentation of power in China, creating opportunities for corruption (Martin 2015):

1. Accountability is top-down with little societal input or transparent monitoring, creating pervasive information asymmetries, and hierarchical pressure is possible

2. Decentralized personnel control enhances loyalty to individuals rather than to a system of rules

3. Perceived windows of opportunity to become rich, followed by stagnation

4. Fragmented bureaucracies with unclear and bargained competences and lack of transparency in decision making encourage "closed shops" of corrupt behavior

5. A culture of "governing by experiment" and "adjusting policies to local conditions" which contradicts formal rules

6. Weak formal institutions: "Rule of Man" rather than "Rule of Law"

7. The achievement of national goals and performance pressure allowing for a breach of compliance agreements at the institutional level

To summarize, it can be stated that in China, we face the situation of a powerful party-which represents the government in the Triple Helix on a different recursion level-but a formally weak governance of policy implementation, lacking formal procedures for organizational development and implementation governance. There are strong interest groups, and the policy process is dominated by bargaining in a period of turbulent and rapid growth of the national economy characterized by a fastgrowing private sector, and a significant state sector, concentrated in mature industries (e.g., energy, telecommunications) which in parts are extremely wealthy. At the same time key industries and inputs (e.g., land) remain heavily regulated; this is also the case at the local level (Martin 2016).

The picture the political economy draws is supplemented by laws and regulations that are often imprecise and complex or missing, while ownership structures are often opaque. Nonetheless, China operates with an understanding of law and moral justice that is highly politicized and substantive rather than formal. Security lies ultimately in conforming to political priorities and the dominant power blocs, not in conforming to formal law. However, politics in times of rapid growth are in a state of constant flux. Constant change in turn feeds insecurity with regard to appropriate behavior.

\section{China and corruption}

Many authors have considered the connection between decentralization and corruption (Birney 2014; Dong and Benno 2013; Fishman and Gatti 2002; Thun 2004). Others, such as Fan et al. (2009), compared different countries in order to determine how political decentralization affects the frequency and costliness of corrupt officials extracting bribes. Among other things, Fan et al. concluded that reported bribery was more frequent in countries with a larger number of government or administrative levels and a larger number of local public employees (Fan et al. 2009: 14). 
From the early 1970s onwards, China started to govern the country in a decentralized manner. Cross-national indicators suggest that the PRC (People's Republic of China) is one of the most decentralized countries in the world. The most widely accepted measures of decentralization focus on the subnational share of total government expenditures (or revenue) (World Bank 2012). Thus, China is unusually decentralized, even following the 1993 reforms that sought to partially decentralize the revenue collection system. In 2002, local governments accounted for nearly $70 \%$ of all government spending and post-1995 China ranks among the most decentralized countries in the entire period, 1972-2000, for which the IMF has compiled this information (Landry 2008).

Political decentralization in China implies that local governments have the responsibility for governing "their" local economy, delivering public services, or gathering fees and taxes. How local governments reacted to this challenge differs enormously, depending upon the institutional settings, sectorial focus and the specific economic situation. Local governments were entitled to collect revenues from taxation of private firms or from profits of state-owned enterprises (Martin 2016).

In addition to these differences, there was strong competition between the different regions and between local governments. Competing with each other in terms of economic success, money, and power makes use of cooperation and so-called helping networks, or guanxi, with the business sector or the central state government in order to achieve political objectives (Martin 2016). In this situation, officials have a large operating space and it is understood that "making money" is something the governments are permitted to do, benefitting is tolerated, and revenues are often used at the discretion of local officials (Hillman 2010). Up to the present time, local politics has been driven mainly by competition over revenue and the search to generate new revenue streams, for the benefit not only of local officials but also for regional infrastructure and welfare projects. Changing the order also had the negative effect that funding for the local community dwindled.

The fight against corruption in administration has a long tradition in China. Early rules implemented by Confucius spoke out against "perishable behavior" which today is given the term "corruption". There were several forms of sanctions when, for example, officials accepted a gift. So-called censors had a duty to monitor officials; sanctions were draconian. In contrast, nepotism has not always been something to be punished, buying public offices has not been condemned (Wang and Woo, 2011, and central bodies-such as the Central Commission for Discipline (CCDI)- have never been independent of party and central government. ${ }^{5}$

Behavior that was considered corrupt by the interviewees is covered by the following. ${ }^{6}$

a. Bribery: selling offices or regulatory favors

b. Levying "fees" and "charitable donations"

c. Expropriating private owners in questionable, to a greater or lesser extent, legal circumstances

d. Embezzling public funds

e. "Grey" use of public funds: for example, on "entertainment", banqueting, karaoke, and "fun"

f. Benefitting friends and family in business: insider privatization, state procurement, acquiring shares before Initial Public Offerings (IPOs), using connections to enter regulated industries 
g. Requisitioning public land hitherto leased to farmers, at varying levels of compensation

h. Extracting rents via monopolistic positions

i. Procurement contracts and invoicing tricks

j. Keeping profits of the state enterprises within the state enterprises instead of paying them out as dividends to the owner (the state/the "entire people")

k. Gift-giving to potential partners

l. Lobbying (money for favors)

Martin (2016: 187, 257) explains that not all of the mechanisms by which this took place were illegal in the eyes of the interviewees-some were implicitly sanctioned by the Centre-but they all occurred through institutions and processes defined and controlled by local officials rather than central (or provincial) state regulation, and rested ultimately on the threat of closure or some other retaliation if owners did not pay up. Granovetter states that "extortion (in which payment is demanded rather than offered) by those socially superior from those of lower status, however, is likely to be accepted more routinely" (Granovetter 2007: 159). This routine corruption was not explicitly mentioned in the interviews.

The most common processes through which extraction by state entities seems to have taken place was levying fees and "fines" and soliciting charitable donations ${ }^{8}$. Local-state authorities have considerable discretion to set (invent) fees and fee schedules. What makes such fees particularly attractive is that the revenue they generate generally does not need to be shared with higher levels of government (Martin 2016: 187). High levels of extraction were possible because local officials had substantial power to close or obstruct privately owned businesses. In times of transformation of the Chinese energy sector and with a rising climate awareness of the population, this becomes a genuine threat to the region and local industrial clusters. However, this is not unique to coal mining: property rights are weak across China's private sector and high technology zones fall under the same scheme (Clarke et al. 2008). Many innovative and large manufacturing industries in the high technology zones are being established and expanding on valuable land or "greenfield" sites and green belt policies are difficult to implement in urban agglomerations (Gebhardt, interviews in 2015). ${ }^{9}$

\section{The coal mining sector and the system of corruption}

During the last decade, Central Government sought improvement of the production capacity of coal mines, the technological upgrading of the industry, the regional development of Western regions, and to limit the effects of the industry on air pollution. This has been implemented by a drastic policy change involving closure and reduction in size of mines ${ }^{10}$ and the nationalization of mines to gain greater control in order to initiate organizational change and transform this large but nonetheless highly fragmented industry. However, a senior researcher from the Energy Research Institute of the National Development and Reform Commission (NDRC) stated that accidents were the key reason for the Shanxi's radical restructuring and nationalization of the coal mines (Martin 2016: 277). ${ }^{11}$

At the dawn of the Reform Era in 1979, SOE (State-Owned Enterprise) mines accounted for the greater proportion of coal production (83.3\% of total output). The 
remainder came from the "Township and Village Mines" (TVMs; or, as they were then still commonly known, "Commune and Brigade" mines). The state sector consists of two main categories: "Key State-owned Mines" (KSOMs) and "Local State-Owned Mines" (LSOMs). ${ }^{12}$ In 1998, ownership of all but two KSOMs was transferred to LSOM status in the provinces, with the Centre only retaining ownership of Shenhua and China Coal (the two largest and most profitable coal-mining SOEs). The resistance of locals to this transformation style was high. ${ }^{13}$ The interdependency of anti-corruption policy and transformation in the mature industry was further fuelled by the media which reported on accidents and corruption cases to overcome resistance on the local level. The smaller-scale private mines generated large numbers of jobs-which were lost when these mines were closed. Many mining regions in Shanxi and elsewhere experienced significant employment problems after nationalization (see: Martin 2016: 149; interviews with an official from a municipal coal industry bureau in Shanxi and three interviews with journalists specializing in energy issues).

Martin (2016) noted that in local networks power rested with factions which controlled key positions in the local party-state and economy and could function as brokers in the social network. They were based on bureaucratic patronage, family, native-place, and school ties. These cultural resources gave cliques an emotional depth and thus long-term stability. Local networks inherently had the ability to influence the formal assessment system and the opportunity to use state positions in order to channel resources via public contracts, regulatory powers, control of key state and private firms, and control of the means of violence. These resources in turn were used to acquire further valuable offices. Local networks can reach out to the provinces or even the Centre. In times of transition, local leaders can either be members of local networks, or outsiders having no local connections. The latter are appointed for short terms and are expected to produce results quickly for promotion and probably bribes (i.e., earn returns quickly on past performance, and the means for future "investment"). Therefore, they are reliant on locals for information and cooperation. Extreme situations apart, these characteristics will be strong incentives to conform to local political-business interests, and not to "rock the boat" (Martin 2016).

Political governance (party), ${ }^{14}$ structure (decentralization), cultural pattern (networking and gift-giving society), and the abundance of financial investments ${ }^{15}$ form a socio-economic system that increases pathologies, such as:

- For political control, the assessment system de facto remains focused on economic and fiscal targets.

- There are pervasive problems with the implementation of policies that reduce local rents.

- Extensive social conflict and low-level violence becomes a problem for the government.

- Salary rises in the administration did not alleviate the problem. ${ }^{16}$

According to the study, the best example to illustrate this is the use of land, which must be considered the main source of local-government revenue in China today and is highly relevant for high tech zones (Gebhardt, interviews with CEOs of foreign firms carried out in the period 2014-2016). Zhou briefly illustrated the issue of land use in 
her case study on the Triple Helix concept and the North Eastern University (Zhou 2008). Officially, the objectives of central government policy are to preserve agricultural land. However, guaranteed compensation is widely disregarded, and land sales remain an easy way of generating revenue (via re-zoning and re-sale), GDP growth, and "political prestige projects". This is a way of profiting privately and benefiting patrons and the "shadow state" through established routines such as collecting fees and kickbacks, and giving contracts to construction and development firms. ${ }^{17}$ It was very common for officials to hold coal-mine shares via their families or friends, and several cases were disclosed during anti-corruption campaigns. ${ }^{18}$

Up to the mid-2000s, private investors seem to have mostly held mines through structures such as leases, entrusted management or rental agreements. While the details of these arrangements no doubt varied tremendously, the basic structure seems to have been as follows: The mine and the underlying coal concession remained formally the property of the village or township, to which the mining licenses, too, were made out. The private investor then leased the use of the mine from the village for a fixed number of years, albeit often on a relatively short-term basis (i.e., only for a few years). During this period, the investor was responsible for operating the mine, paying all taxes, fees, and wages, as well as a rental fee to the village, while keeping all residual profits (Martin 2016: 257: interview 929). De facto, the mine was privately controlled, but nominally it remained registered as collective property, owned by the village or the township (Martin 2016: 30). Structures of this kind seem to have been preferred to outright sales because the legality of private coal-mine ownership and of privatizing coal resources was unclear and because, to be formally correct, sales and transfers of rights would have required approvals from higher levels. Because of this, the real (private) owners often seem to have established multiple layers of (nominal) legal representatives and lessees between themselves and the village or township from which they had obtained the mine, making it difficult to establish who really owned the mine. Opaque and complex legal structures of this kind also created obstacles for private investors to raise new capital or cooperate with other firms or institutions to upgrade their mines (Caijing 2003; China Comment 2007; China Economic Times 2007; Southern Weekend 2006b; all cited in Martin 2016: 200).

"If the economic dimension meant that the bargaining power of mine owners was weak, coal mining's political position as a heavily regulated industry under severe policy pressure provided local governments with powerful levers vis-à-vis mine owners. While actual policies were formulated by provincial and central authorities, key decisions about implementation - that is, which mine would be affected, and how, by a particular measure - were made at the county and municipal levels. Local authorities were also responsible for day-to-day supervision and enforcement of mining regulations" (Martin 2016: 191). These patterns also remain common for activities linked to innovation in special zones, which are characterized by high-level political attention of the central government and execution of policies by local agencies. In addition, land remains a limited resource: land, and the logic of real estate construction and profit to fill the parks, overwhelm the policy to form an integrated innovation cluster that involves local SMEs and firms and encourages self-organized institutional interaction (Gebhardt 2013). Equally, entrepreneurial university and firm interaction in innovation clusters remains a grey zone due to the lack of regulatory frameworks. 
"In coal mining, central-State Enterprises dominate the industry. The problems of collecting fees and 'donations' are multiplied, because the industrial sector is profitable and dominated by a highly regulated industry and long-standing institutional and individual relationships. However, the economic and political characteristics of the coal industry probably exacerbated the relative weakness of mine owners. On the economic side, coal's status as a valuable but entirely commoditized product involving large capital investments meant that mine owners had only limited bargaining power with officials" (Martin, 2016: 190).

The mining sector shows structural differences to other localities, and this situation applies for other coal mining regions and mature industries in general. In high technology agglomerations and innovative industries, recruitment is more diverse (i.e., old networks are weaker) and more rigorous with regard to social selection mechanisms (merit and suitability for the post). Officials have greater financial options and prospects for promotion, and salaries and benefits are higher. In lagging or old industrial regions, opportunities are more circumscribed and functionally specific powers dominate a less dynamic socio-economic system. The rigidity (and transparency for insiders) of networks allows the central government to become more actively involved in these regions. However, in times of high energy consumption, and future need of it, giant conglomerates mainly in sectors such as energy, IT, telecommunication and construction SOE, and individuals in this industry, are extremely wealthy. High profits and preferential access to credit and state investment programs are attainable in this period of growth of sectors without opening the closed shop of the old and mature industries. For outsiders, these historically grown relics are very opaque, and financial profits have largely been retained in the enterprises rather than being paid out as dividends. In the absence of new players, governance, shareholder value mechanisms, salaries, benefits, and grey income remain in the dark. "As a main characteristic executives hold ministerial rank, and even outrank their government regulators: the executives outgun the regulators in terms of staff, money and technical expertise. Many executives in the energy sector are the children of top leaders, so that the sector can be seen as a mechanism for redistributing wealth towards the party-state elite" (Martin 2016: 172). ${ }^{19}$

There is no systematic research on corruption in high technology industry in Triple Helix-based regional innovation systems. However, we find indications pointing towards its existence. Generally, systems of corruption correlate with major investments either by industry or state. Recent show trials have revealed that members of the political elites shifted money from old sectors to high tech development zones (Ahlstrom et al. 2006; Cao 2004; Shapira and Wang 2010). In this way, cronycapitalism of party members concealed fortunes not only in prestigious real estate and assets abroad but also in competitive markets, such as high tech, healthcare, and entertainment (Bay et al. 2014). As a result, corrupt behavior impedes the modernization of old industries because it can act as a hidden obstacle to implementation of innovation policies. A dynamic Triple Helix-style cooperation between universities, industries, and local government is still regarded with suspicion by central agencies and some institutions shy away from too much interaction although, at the same time, they see the innovation cluster model as a state of the art innovation model. ${ }^{20}$

In high technology development zones, patterns such as (re-)use of land, substantial regulation, the role of officials, the reporting of economic indicators to the central 
government, and the fees paid to officials are also to be found. There is more money to be earned in innovative industries and the anti-corruption campaign has introduced an additional risk regarding corrupt behavior and thus triggered the fees that have to be paid to shift the money to more appropriate investments (Anderlini 2010). To what extent did the monies, the hidden investment schemes and the culture of rent-seeking travel from old to new industry and from a system of corruption to a new regional innovation system? There is initial evidence that with the transfer of investments the culturally anchored system of corruption transferred to new locations and industries.

\section{Findings and conclusions}

As in many nation states, decentralization of administrative power in China is accompanied by the implementation of high level concepts to a culturally and organizationally very specific situation. These concepts are as follows: innovation clusters based on the Triple Helix model, transformation and modernization of industries to meet global high tech standards, and to provide solutions for major challenges such as the global development goals. The transition to a market economy under conditions of authoritarian rule, political decentralization, low societal participation and lack of transparency, and within a weak, unclear or non-existent legal framework, offered the powerful and connected elite in the coal mining sector a major opportunity for wealth accumulation and possibilities for further investments into innovation clusters, new industries and places and the criminal or legal concept of corruption may apply in many cases. A culture of seeking rents, which has long shaped a socio-economic system, facilitated the establishment of crony-capitalism.

Long-lasting networks of administration and state-owned industries-exemplified by the coal mining sector-also tend to support routine corruption, which is even triggered by the dependence of new industries on the energy sector and the influx of money to secure administrative authorizations. The decentralization and large flows of money collided with these closed shops where informal rules persisted and foreign companies as well as Saxenian role types of Argonaut entrepreneurs, entrepreneurial universities and science based spin offs are a rare find. Rapid regionalization and decentralization policies followed again by nationalization of industry did spur corruption, because drastic change and insecurity (which included job losses and loss of local welfare programs) occurred. Enforcing central economic targets, and the power play to generate obedience to national goals, shifted loyalties to informal ties. Tacitly, the (unintended) coupling of transformation, modernization, and anti-corruption brought about a systemic risk for future economic growth due to the co-optation of Triple Helix-based regional innovation systems by routine corruption.

Networking and interaction among Triple Helices is expected to enhance the conditions for innovation. Alas, the same holds true for corruption. The prevalence of belief systems and persistence of the old order and routines is something the country must now either address in a new openness and with a systemic anti-corruption approach, or face further stagnation. Draconian punishment of individuals and show trials must be seen as crisis intervention rather than an effective means by which either to erase the system of corruption or to spur transformation and modernization. The lessons for Triple Helix constellations in high tech zones lie in the obvious: governance in innovation clusters must not be restricted to technological content and formalities but 
must openly address and manage cultural change and change of practice and routines in local relationships having a new role, and also with room for reflection of this new role for local authorities, universities, foreign firms, SOE, and small firms. If structural change, organizational development and societal impact of innovation are not managed and flanked and reinforced by regulation and organizational incentives for the new order corrupt patterns and informal routines will be transferred from old institutional settings to high tech sectors, in particular when the organizational vehicles for innovation are networking constructs. It appears that the management of the transition phase and the repurposing of social networks are critical success factors for innovation and modernization. As a consequence, innovation polices that comes with an institutional approach and ignores local, "closed" networks will be ineffective in upgrading the economy.

We have addressed corruption in a new perspective of "organizational deviance" in social systems and in an interdisciplinary mode, taking cultural aspects, policy, and polity into account to understand the socio-economic nature of corrupt systems. New forms of innovation policies, and concepts such as Triple Helix-based regional innovation systems, can bring about changing interpretative schemes of cultural traditions and disrupt corrupt patterns when the transfer of behavior and values is made a management issue ab initio and the transition is professionally managed. This new approach offered a renewed perspective on the problem of capital flight and "elite flight", which not only suggests corrupt behavior but also represents an increasing insecurity whether or not the socio-economic context is changing for a "New Deal" and for a new code of conduct. New forms of innovation policies, and concepts and a new role of the government in the Triple Helix model can bring about changing interpretative schemes of cultural traditions and disrupt corrupt patterns. However, these policies, concepts, and roles must address the underlying code of belief systems. They should not be restricted to the description and transfer of elements of the innovation model but, rather, should be open to management issues of organizational development (behavior, rules, and code of conduct versus the old routines, identification, and solving of conflicts of interest from conflicting political/organizational objectives and norms) or they might unintendedly facilitate the transportation of corrupt systems and induce cognitive dissonance in members of the clusters (i.e., coping with the conflict of interests: rule of law rather than personal loyalty to long established peer group members and networks that may-at some point-deviate from the first).

Establishing regional innovation systems can signal a new culture, characterized by the entrance of new players, as well as by a collaborative leadership style and increased transparency. Innovation relies on creativity and flexibility with regard to norms, and this needs to be reflected upon as new rules for open cooperation and leadership become necessary. Good cluster governance must make informal practices explicit, name the conflicts of interest and encourage the self-reflexive powers of clusters which must be seen as a new organizational entity. Globally integrated firms, driven by returns on investment, may transport compliance rules and participative leadership style to new locations and Triple Helix constellations, but are destined eventually to fail because business relies on adaptation to the local culture. In this systemic approach, corrupt behavior is an outcome or an indicator of the experienced fragility of the political economy and the societal changes in China and cannot be addressed in the conventional, criminal way alone. 
The study proves that corruption is not a stand-alone legal concept related to individual misbehavior, bribery, and fraud but, rather, is a problem of cultural alignment and communication in networking relationships. The search for stability in times of dramatic change and insecurity increases the problem of corruption and takes on the form of a vicious circle which cannot be broken by further legal regulations that target the business and individuals rather than the system of industry, university, administration, and society.

Although the degree and nature of corruption is country specific and determined by cultural traditions, there is a convergence of behavior in times of large-scale transition and change. The innovation interviews and the study by Martin (2016) on the coal mining sector illustrated that individuals are well aware of the nature of corrupt behavior and gave precise information of cases and the operational mode; but, for themselves, these individuals tended to make decisions in favor of their peers and according to the code of conduct of their organizational context. The study shows that corruption is a systemic concept that must be seen in the light of socio-economic development and as being embedded in the organizational reward system of the organizational context.

\section{Outlook: innovation policy needs governance of implementation}

The paper addressed the blind spot of culturally and organizationally anchored corruption in innovation with the concept of organizational deviance. The reconsideration of interviews carried out in coal mining and with experts in innovation illustrated the ambivalence and limits of the legal concept in corrupt systems and highlighted the crucial role of local and central government in networking organizations and transformative processes.

The probability of regressive behavior and corrupt routines is increased by the insecurity that comes with the change dimension of transformation and the shake-up of organizational settings. Transformation of society and of the economy are two sides of the same coin. For the economy, we see a power play to disrupt old structures at the local level in order to shift power to the vertical networks. Individual misbehavior or occupational corruption and personal gain are revealed, or used to eliminate opponents, but the organizational routines remain unnoticed and intact. Legal detection of individual corruption can also be considered as collateral damage alongside the modernization of the energy sector. In a Quadruple Helix analysis, the transformation of society shows the societal illegitimate behavior of personal enrichment of an elite that hampers further advancement of the Chinese economy and is contrary to the idea of a harmonious society and equal opportunity. It also reveals the absence of concepts of governance for networking organizations such as innovation clusters, for technology transfer activities and scientific entrepreneurship. There is room for improvement here, and new concepts of cluster government must accompany the implementation of innovation strategies. One should not forget that politically driven Western innovations clusters also started out with the best intentions. Do they meet the political and organizational targets in an effective and efficient way?

In this line of understanding, rapid growth is ambivalent: major investments and rapid growth bring a shift in economic boundary conditions which agitates the social fabric of formal and informal rules. Within the transition of society, organizational 
deviance may be an ephemeral phenomenon until new arrangements and repertoires become accepted modes of functioning.

Thus, the translation of high-level concepts to the local situation appears to be a critical situation and a tipping point for a change of belief systems, the buy-in of a critical number of players and for new organizational routines. It appears that, increasingly, regional innovation strategies related to upgrading economies are adopting the organizational principles of interaction in order to build growth on the basis of innovative networking initiatives. The study shows that this interaction can be ambivalent. The formation of new collaborative environments is relevant not only for acquisition but also for distribution and use of know-how. Interaction needs a true north-which consists of the values of the social contract, legal security, an open dialogue on formal/ informal rules and regulations for cooperation, recombination, or merger, on stakeholder management as well as on good governance of networks. It is easy to say that, "as members of innovation clusters, all players can and must advance their innovation and networking capabilities and improve their performance and self-reflective capacity" (Etzkowitz 2002; Kaufmann and Toedtling 2001). These innovation clusters hold no more than the promise to change the rules of the old game and transport different cultural values and behavior which supersede clan loyalty as well as family and friendship ties in case of conflicts of interest-and nothing else. For this reason, the helix model needs the fourth societal helix in order to provide an opportunity to analyze the change and the break-up of traditional patterns of corrupt behavior linked to closed systems.

Ultimately, negligence of the organizational development of networking organizations, the lack of communication at the meta-level of behavior, and the lack of management of the consensus space between cluster members all constitute a flaw in modernization programs and innovation policy. It should be kept in mind that the Triple Helix model was invented in a context of rule of law and democracy. The Chinese central government started the experiment of modernization in special development zones and, by means of further decentralization of political power, to manage the large numbers of individuals involved, but could not provide the volumes of well-trained administrators at sub-national level and the open societal dialogue that were needed to govern professionally the dimension of change that accompanies rapid growth. However, the vicious circle might be broken by a different set up of collaborative tools and methods, and joint ventures between SOE and shareholder-controlled foreign firms and local agencies as well as the involvement of young local entrepreneurs. If the change of cultures in these clusters is transparently monitored, discussed, reflected upon and openly communicated and managed, these organizational settings can also transform behavioral patterns and belief systems.

The research sheds light on the importance of good cluster governance as an effective anti-corruption scheme in the political economy of fast-growing economies and in Triple Helix-based regional innovation systems. This requires further and wider research and a new consideration of anti-corruption schemes in innovation as a systemic concept and interdisciplinary subject. The link between regional innovation systems and systems of corruption might be a missing factor which explains both the failures to implement innovation policies effectively and efficiently and the diversion of funding in regional innovation projects not only in China but also in many BRIC countries (Gouvea 2013; and many others). As a result, it can be argued that the 
relevance of governance, cultural tradition, and change management must be openly addressed in innovation programs.

New forms of networking which address innovation provide a new critical mass that can bring about changing interpretative schemes of cultural traditions and break up established, corrupt patterns in the society. It appears that China is now on the verge of a significant societal and economic transition. The dualism is apparent: national and mature industries such as those of basic commodities, natural resources, defense and the energy sector are in danger of formally decoupling themselves from the rest of the economy, taking the informal patterns to other countries and regions or, via elite investment, to new industries such as ICT (Information and Communications Technology), or medical or biotechnology sectors. The key controls for changing the system are change management, transparency, professionalization of administration, communication, and self-reflection of changing cultural patterns in Triple Helix constellations and in a wider context of society.

\section{Endnotes}

${ }^{1}$ Heidelberg University runs a large international and interdisciplinary research program on corporate corruption in BRIC countries and in Europe (Switzerland, Germany). The team analysis cases which can be explained neither by the personal enrichment of some utility maximizing nor greedy perpetrators. These cases are not adequately fought by corporate departments and compliance schemes. They test the self-regulation of organizations as an explanatory approach. Assuming that anticorruption will be more effective if it does not simply rely on formal regulation and corporate compliance departments, they provide social mechanisms of self-regulation within companies as an explanatory factor. Research team: Pohlmann, Max-Weber-Institute for Sociology; Dölling, Institute of Criminology; Hermann, Institute of Criminology; Dannecker, Institute for German, European and International Criminal Law and Law of Criminal Procedures. Heidelberg University 2017.

${ }^{2}$ The Triple Helix model of university-industry-government relations offers an organizational prototype for initiating and facilitating innovation in many regional contexts. In China, many high technology zones are based on Triple Helix principles (Irawati and Gebhardt 2013; Gebhardt 2013). The Triple Helix model comprises three key components: university, industry, and government (Etzkowitz 2002; Etzkowitz and Leydesdorff 2000). The government provides direct and indirect support and channels many public science and technology investments; industry engages in transfer and commercialization of technology and the production of innovative products and services; and university and science deliver academic contents and research results, to educate and train students to become entrepreneurs and skilled manpower. All these system components are interlinked by multiple knowledge flows, interactive learning and competence-building. The Triple Helix-based regional innovation system works on consensual terms and is embedded in a regional context. The concept transports the idea of open interchange of knowledge.

${ }^{3}$ Good governance is a term not specified but used in the international development literature to describe how public institutions conduct public affairs and manage public resources. Governance according to United Nations ESCAP (Economic and Social Commission for Asia and the Pacific) is defined as "the process of decision-making 
and the process by which decisions are implemented (or not implemented)". See: United Nations ESCAP Manual, What is good governance? July 10, 2009. In: http:// www.unescap.org/sites/default/files/good-governance.pdf accessed 28.05.207

${ }^{4}$ Transparency International, sub-titled "The global coalition against corruption" has as its Mission Statement, "...to stop corruption and promote transparency, accountability and integrity at all levels and across all sectors of society. Our Core Values are: transparency, accountability, integrity, solidarity, courage, justice and democracy." See: https://www.transparency.org/ (accessed 29 May 2017).

${ }^{5}$ For details of the Central Commission for Discipline (CCDI) see: http://www.ccdi.gov. cn/jlsc/ (accessed 15 September 2016).

${ }^{6}$ Expert interviews: China (Martin 2016). Questions asked included: "What kind of behavior would you consider being corrupt?" with the accompanying request, "Please explain from cases you have heard of".

${ }^{7}$ Local-state entities (e.g., government bureaux) and individual officials were able to draw off large sums of money from industry (in this instance, coal mines) through channels other than the formal taxation system, in return for permitting them to operate and without providing a legitimate service in return (e.g., inputs such as water or electricity). In an interview in 2007, the head of the State Work Safety Agency, Li Yizhong, spoke of cadres and their relatives owning shares or running mines and extorting bribes as common across the country (Martin 2016:190, interview).

8"Charitable donations" functioned in much the same way as fees: local authorities would simply set a fundraising target or define a purpose for which moneys were to be raised, and then "invite" local firms to contribute. While "donations" and fees were to some extent "universal" payments (i.e., they were charged of most or all firms active at given time and place), individual payments by single firms to a particular office of course also occurred. For example, coal boss Meng Zhaokang a former local official who owned mines in Xiaoyi, a county-level city in Shanxi, and was for a time the richest man in the area, gave large sums of money to various bureaus in Xiaoyi and Lüliang Prefecture by purchasing old buildings from them at inflated prices (see: Martin 2016: 187).[...] Mining enterprises paid around 40 separate fees (Interview). Not all fees had even a nominal link to the coal business. In some locales in Guizhou, coal firms paid an "education fee" (Interview). One Guizhou coal boss estimated that he spent at least $10 \%$ of profits every month on fees and "building relationships" (Southern Weekend 2007b). In 2009/2010, the government of Xinmi County in Henan ordered local mines pay an additional ad-hoc "contribution" of RMB 20 million on top of their regular tax burden (Caijing 2010d). In 2011, Shenmu county in northern Shaanxi county obtained commitments from local enterprises to donate RMB 3.8 billion over the Twelfth FiveYear Plan period, while neighboring Fugu county raised at least RMB 1.3 billion in donations from 2007 to 2010 (Chinese Business View 2011; EO, 2012b). In the counties of one Shanxi municipality, the TVMs were expected to provide the local governments with between RMB 5 and 30 million annually over and above the regular taxation to fund "public projects". Testimony of this kind about the scale of informal extraction from the private mines could easily be multiplied. In part, these moneys were used to fund legitimate state activities. Shenmu and Fugu in particular ploughed large sums raised through "donations" into providing free health care and education for local residents as well as social security payments. But it seems that often these ad-hoc levies on 
mine owners were used for what may be best described as conspicuous government consumption. When the Linfen City Public Security Bureau wanted to construct a new administrative building, it sent its staff out to collect fines from coal bosses. Everyone was given a collection target, including staff from offices entirely unrelated to mining. Over RMB 100 million was thus raised. Collection of fines was only reigned in after someone deposited a package of explosives in the Bureau's courtyard (Oriental Outlook, 2008). In 2003 in Xingren County, Guizhou, the county head financed a large cultural festival with "voluntary" donations from mines (Southern Metropolis Daily 2006), while back in Linfen Prefecture, a county head obliged local mines to "donate" up to several million yuan each to finance the construction of a replica of Tian'anmen Square as well as what is apparently the world's tallest ceremonial gate complex. Extraction by individual officials proceeded in similar ways. Much probably took place through bribes, especially when licenses had to be obtained or renewed, or in the context of "handling" mine accidents. Thus, the former Head of the Henan Coal Mine Safety Inspectorate amassed at least RMB 19 million in bribes over an 8-year period in the mid2000s (Caixin Online 2010). But probably even more prevalent was stockholding by officials and their relatives in mines. In 2005, this was made illegal as were cadres. Extraction by individual officials proceeded in similar ways. Much probably took place through bribes, especially when licenses had to be obtained or renewed. "[...] prevalent was stockholding by officials and their relatives in mines. In 2005, this was made illegal” (Martin 2016: 188).

${ }^{9}$ Looking out of the window, the consultant was informed that the dense industrial zone spreading right before the company building was officially declared a "green belt area". (Gebhardt 2012; City management, interviews in consulting).

${ }^{10}$ The Sixth Five-Year Plan (1986-1990) even called for prioritizing the construction of "small and medium mines", i.e., Town and Village Mines over that of "large-scale mines" (i.e., KSOMs), a statement which marked the high point of central-state support for the TVM sector. The Plan encouraged localities and departments to pool funds for smallmine development and to extend additional support to the best TVMs. In sharp contrast to policy 20 years later, when such shareholding was made illegal, local cadres were urged to invest their personal savings in TVMs (Interview: Martin, 2016: 654)

${ }^{11}$ What happened in essence in these years was that the Center strongly reaffirmed its concern that the various ills bedeviling the coal industry-accidents, pollution, low recovery rates-be brought under control, and stipulated that it wanted the number of small-scale, private mines-which were at the heart of these problems-to be greatly reduced. How exactly this was to be achieved, however, was largely left up to the provinces. According to interviewees familiar with policy making in China, this is fairly typical: central authorities mostly confine themselves to setting broad strategic objectives and are reluctant to give provinces detailed orders about how they should go about achieving these. (five interviews: Martin, 2016: 235)

12“Key State-owned Mines". These are large concerns that played a central role in the coal production and distribution system. They provided the bulk of the coal distributed via the Central Plan (up to 1993) and most of the coal allocated administratively at submarket rates to electricity companies and, since 1993, through various successor mechanisms to the Plan. Throughout the history of the People's Republic, the KSOMs have formed the main block of the state sector, enjoyed the best access to state investment 
funds and bank credit among coal firms and generally had the best mining equipment and working conditions in China's coal industry, as well as the best safety performance. Between 1979 and 2010, they always accounted for around 50\% of total coal output. Until 1998, these enterprises were owned by the central government. "Local StateOwned Mines" are generally smaller enterprises, usually owned by sub-provincial (county and municipal) governments. Non-state "Township and Village Mines" were partly collectively owned and partly private, but with private ownership dominating by the 2000s (see: Martin 2016: 49).

${ }^{13}$ Alluding more directly to the effect of nationalization on the flow of bribes local officials had hitherto enjoyed, the head of a local work safety inspectorate told a journalist that "the closure of the private mines has had a huge impact on us, though we cannot speak about this openly as it involves certain unspoken rules. He went on to explain that, 'when you possess veto power, all kinds of benefits will flow your way. Even if you want to dodge them, you won't be able to'. With the large SOEs, however, his office held no such 'veto power', causing the stream of benefits to dry up. Interviewees too stressed the disapperance of grey and black earnings as a key reason for local officials" opposition to nationalization (seven interviews: Martin 2016: 210).

${ }^{14}$ The "Party Elite" consists of individuals of ministerial rank or higher who have opportunities for enrichment at this level. Importantly, the interviewees found it hard to say to what extent this was technically illegal, because business people have strong incentives actively to court these Party Elite individuals.

${ }^{15}$ Encouraging joint investment projects between local private and provincial and central-state firms served to "balance interests" between the localities and the SOEs, thus making the locality more supportive of investments by higher-level SOEs, and would help to drive local industrial development and the growth of local (private) businesses. Involvement of a local partner would make it easier for the local government to tax the venture in question, absorb local private investment capital and keep it in the locality (instead of seeing it flow off into e.g. Xi'an or Beijing real estate), and open up new development possibilities for the private firms by facilitating their participation often very large and capital and technology intensive downstream projects (coal refining, power generation, etc.) that they would have found hard to get into by themselves. According to several journalists as well as an interview that the deputy head of the Shaanxi Development and Reform Commission gave to the 21st Century Business Herald (Martin, 2016: 292).

${ }^{16}$ In 2015 , China's 39 million civil servants and public workers received a salary raise of at least $60 \%$ of their base salaries as part of an overhaul of their pension plan. See: Caixin Online, 22 January 2015 (http://english.caixin.com/2015-01-21/100776914.html).

${ }^{17}$ http://www.scmp.com/news/china/article/1514591/top-national-energy-administrationofficial-held-widening-graft-probe. Accessed 25 May 2017.

${ }^{18}[. .$.$] Numerous cases of officials' owning stock in private mines via proxies or via$ their families were also disclosed in Shanxi in the course of several anti-corruption campaigns begun after 2008. "[...] In an interview in 2007, the head of the State Work Safety Agency, Li Yizhong, spoke of cadres and their relatives owning shares or running mines and extorting bribes as common across the country" (Martin 2016: 190).

${ }^{19}$ Shanxi's party secretaries from 2005 to 2014 were Zhang Baoshun and Yuan Chunqing, both of whom made their career in the Communist Youth Leaguge, which 
is considered the core base of Hu Jintao's faction. The Shanxi governor in 2007-2008, Meng Xuenong, under whom the nationalization plans were developed, also was a Youth League cadre. Hu Jintao's key aide and Chief of Staff, Ling Jihua-also for long years a cadre in the Youth League-is a Shanxi native, and in the 2000s several of his close relatives and friends were senior Shanxi politicians. The validity of this interpretation (that Shanxi was a Youth League province) was also emphasized [to me] by a Chinese academic. The Shaanxi governor from 2006 to 2010 was Yuan Chunqing, who spent most of his early career in the Communist Youth League. His replacement as governor (2010-2012) and current Shaanxi party secretary (since 2012), Zhao Zhengyon, too, is a former Youth League leader. Zhao Leji who served as Shaanxi Party Secretary from 2007 to 2012 is reportedly a close confidante of Xi Jinping. The Xi family has very deep connections to Shaanxi (Interviews: Martin. 2016: 139).

${ }^{20}$ When the author asked for active projects in the innovation cluster around Tsinghua Universities, one CASTED member said, "I hope they will not cooperate too closely". Managers of foreign firms stated that they work with students or to a small extent with single professors rather that with faculties or institutes. Asked for the innovation model for improving agrarial science in the western regions professors of Tsinghua would answer that the best knowledge and technology transfer model would be to send experts to the regions. In IMAU, researchers would say that the impact factor is a politically constructed figure and cooperation with local firms is in general a good thing but science-to-science research in one discipline must be the priority for the time being. Foreign top universities were the preferred partner (interviews CASTED, Tsinghua and IMAU Universities carried out by the authors 2015-2016). Proposals to set up Triple Helix-based innovation clusters that anticipated university-industry and local government interactions in the zones were rejected by the high technology zone managers and managers made a settlement plan for firms according to sectorial compartments. Meeting and interaction was planned in leisurement and sport facilities (interviews by the authors, 2015-2016: Beijing consulting company and TEDA). Companies like Huawei spend a large amount of money on research and interact with universities and research labs in countries outside China. However, joint programs for joint research projects of Chinese research labs and local industry based on matching funding in China are not (yet?) an innovation policy instrument (Gebhardt 2016; interviews, CASTED). This might change with the new strategy outlined for the Sino-German platform which foresees the involvement of SME as well as industry - science collaborations. (https://www.sino-german-platform.eu/index.php?index=53) accessed 22.07.2017.

\section{Additional file}

Additional file 1: Translation of the abstract into Arabic. (PDF $121 \mathrm{~kb}$ ) 


\section{Acknowledgements}

The author is pleased to acknowledge in particular the invaluable help given by Nicholas Martin in granting permission for access to and use of the data from his doctoral thesis (Martin 2016).

The authors thanks her students of her Master Lab "Management in International Settings" at the University of Heidelberg and especially wants to mention the excellent paper of Backmund S and Bauer C (2015) The issue of corporate giving: Corporate giving in Russia—challenging the morals of German enterprises (Essay). (unpublished).

\section{Funding}

The author confirms that this research received no specific grant from any funding agency in the public, commercial, or not-for-profit sectors.

\section{Availability of data and materials}

Available in the main paper.

\section{Author's contributions}

Christine Gebhardt is the sole author of the paper.

\section{Author's information}

Dr. Christiane Gebhardt holds a master degree in Public Administration Science (University of Konstanz) and obtained her PhD from Giessen University in Political Sciences (Regional impact of R\&D programs in the US and Germany). Her scientific career includes several stations: Assistant Professor at Jena University, Visiting Professor at SUNY and research stays Chicago University, and MIT Massachusetts Institute of Technology in Boston. Her research on China (Foreign SME in China) in 1996 and 1997 was funded by the European Union.

She has been with the Malik Management Institute in St. Gallen/Switzerland for 18 years and currently holds the position of Vice President/Head Global Initiatives. Her assignment to manage the market entry China for Malik has included the establishment of the Chinese Malik Office in Shanghai and the involvement in many local projects.

Christiane was a member of the High Performance Cluster Commission for the German Government and took part in the expert team on Industry 4.0 Smart Service World at the German Academy for Science and Engineering. She is an expert for Chinese SAFEA and European DG Regional \& Urban Growth. Her research is on regional innovation systems linked to Strategy, Governance, and Organizational Design. She has evaluated Chinese, European, and US programs addressing innovation and carries out consulting for larger firms, SME, research organizations, cluster organizations, and scientific startups. Christiane teaches innovation studies at Heidelberg University.

\section{Ethics approval and consent to participate}

Not applicable.

\section{Consent for publication}

Not applicable.

\section{Competing interests}

The author declares that she has no competing interests.

\section{Publisher's Note}

Springer Nature remains neutral with regard to jurisdictional claims in published maps and institutional affiliations.

Received: 6 January 2017 Accepted: 14 July 2017

Published online: 01 August 2017

\section{References}

Ahlstrom D, Yeh KS, Bruton GD (2006) Venture capital in China: High technology investing in an emerging economy. In: Li H (ed) Growth of new technology ventures in China's emerging market. Edward Elgar, Northampton, MA and Cheltenham, pp 261-286

Anand V, Ashforth BE, Joshi M (2004) Business as usual: The acceptance and perpetuation of corruption in organizations. Acad Manag Exec 18(3):9-23

Anderlini J (2010) Chinese officials' children in corrpution claim. Financial Time 12 March. In: Jl Ruan Guanxi, Social Capital and School Choice in China: The Rise of Ritual Capital Palgrave Studies on Chinese Education in a Global Perspective Springer, 2016 ISBN 3319407546, 9783319407548

Ashforth BE, Anand V (2003) The normalization of corruption in organizations. Res Organ Behav 25(1):1-52

Ashforth BE, Gioia DA, Robinson SL, Trevino LK (2008) Re-viewing organizational corruption. Acad Manag Rev 33(3):670-684

Balzer H, Askonas J (2016) The Triple Helix after communism: Russia and China compared. Triple Helix 3:Article 1

Bay C-E, Hsieh C-T, Song ZM (2014) Crony capitalism with Chinese characteristics., Yale Online. Available at http://cowles.yale.edu/sites/default/files/files/conf/2014/ma_song.pdf. Accessed 29 May 2017

Behringer S (2015) Compliance-management. In: Passarge M, Behringer S (eds) Handbuch Compliance International. Erich Schmidt Verlag, Berlin, pp 5-25

Birney M (2014) Decentralization and veiled corruption under China's 'Rule of Mandates'. World Dev 53(C):55-67

Boekholt P (2010) The evolution of innovation paradigms and their influence on research, technological development and innovation policy instruments. In: Smits RE, Kuhlmann S, Shapira P (eds) The theory and practice of innovation policy: An international research handbook. Edward Elgar, Cheltenham and Northampton, MA, pp 333-362 
Breznitz D, Murphree M (2011) Run of the red queen: Government, innovation, globalization and economic growth in China. Yale University Press, New Haven, CT and London

Broadhurst R, Wang P (2014) After the Bo Xilai trial: Does corruption threaten China's future? Survival 56(3):157-178

Campbell J-L, Göritz AS (2014) Culture corrupts! A qualitative study of organizational culture in corrupt organizations. J Bus Ethics 120(3):291-311

Campbell DF, Carayannis J, Elias G (2015) Quadruple Helix structures of quality of democracy in innovation systems: The USA, OECD countries and EU member countries in global comparison. J Knowl Econ 6(3):467-493

Cao C (2004) Zhongguancun and China's high-tech parks in transition: 'Growing pains' or 'premature senility'? Asian Survey 44:647-668

Carayannis EG, Campbell DFJ (2009) Mode $3^{\prime}$ and 'Quadruple Helix': toward a 21 $1^{\text {st }}$ century fractal innovation ecosystem'. Int J Technol Manage 46(3/4):201-234

Carayannis EG, Meissner D, Edelkina A (2017) Targeted innovation policy and practice intelligence (TIP2E): Concepts and implications for theory, policy and practice. J Technol Transfer 42(3):460-484

Chaminade C, Edquist C (2010) Rationales for public policy intervention in the innovation process: Systems of innovation approach. In: Smits RE, Kuhlmann S, Shapira P (eds) The theory and practice of innovation policy: An international research Handbook. Edward Elgar, Cheltenham and Northampton, MA, pp 95-114

Chen S, Jefferson GH, Zhang J (2011) Structural change, productivity growth and industrial transformation in China. China Econ Rev 22(1):133-150

Clarke D, Murrell P, Whiting S (2008) The role of law in China's economic development. In: Rawski T, Brandt L, editors. Cambridge: Cambridge University Press

Cooke P, Leydesdorff $L$ (2006) Regional development in the knowledge-based economy: The construction of advantage. J Technol Transfer 31(1):5-15

Cressey DR (1959) Contradictory directives in complex organizations: The case of the prison. Adm Sci Q 4(1):1-19

Della Porta D, Rose-Ackerman S (2002) Corrupt exchanges: An introduction. In: Della Porta D, Rose-Ackerman S (eds) Corrupt exchanges: Empirical themes in the politics and political economy of corruption. Nomos Verlagsgesellschaft, Baden-Baden, pp 8-19

Dong B, Benno T (2013) Causes of corruption: Evidence from China. China Econ Rev 26:152-169

Edquist C (ed) (1997) Systems of innovation: Technologies, institutions and organizations. Pinter, London

Esser H (1986) Können Befragte lügen? Zum Konzept des "wahren Wertes" im Rahmen der handlungstheoretischen Erklärung von Situationseinflüssen bei der Befragung., Available at: http://nbn-resolving.de/urn:nbn:de:0168-ssoar-66357. Accessed 25 Nov 2016

Etzkowitz H (2002) Networks of innovation: Science, technology and development in the Triple Helix era. Int J Technol Manag Sustain Dev 1(1):7-20

Etzkowitz H, Leydesdorff $L$ (2000) The dynamics of innovation: From national systems and 'Mode 2' to a Triple Helix of university-industry-government relations. Res Policy 29(2):109-123

Fan SC, Lin C, Treisman T (2009) Political decentralization and corruption: Evidence from around the world. J Public Econ 93(1-2):14-34

Fishman R, Gatti (2002) Decentralization and corruption: Evidence across countries. J Public Econ 83(3):325-345

Gebhardt C (2013) Upgrading the Chinese economy by overhauling Special Economic Zones: Innovation model shopping or the emergence of a Chinese innovation model? Ind High Educ 27(4):297-312

Gläser J, Laudel G (2010) Experteninterviews und Qualitative Inhaltsanalyse als Instrumente Rekonstruierender Untersuchungen, 4th edn. VS Verlag fuer Sozi-alwissenschaften, Wiesbaden

Gong T (1997) Forms and characteristics of China's corruption in the 1990s: Change with continuity. Communist Post-Communist Stud 30(3):277-288

Gonin M, Palazzo G, Hoffrage U (2012) Neither bad apple nor bad barrel: How the societal context impacts unethical behavior in organizations. Business Ethics 21(1):31-46

Gouvea R (2013) How the corruption Quadruple Helix affects BRIC: A case study of corruption in big emerging economies. J Politics Law 6(2):1-12

Grabher G (1993) The weakness of strong ties. The lock-in of regional development in the Ruhr Area. In: Grabher G (ed) The embedded firm. Routledge, London, pp 255-277

Granovetter M (1985) Economic Action and Social Structure: The Problem of Embeddedness. Am J Sociol 91(3):481-510

Granovetter M (2007) The social construction of corruption 152-172. In: Nee V, Swedberg R, editors. On Capitalism. Stanford University Press, Palo Alto CA

Gray C (1991) Legal process and economic development: A case study of Indonesia. World Dev 19(7):763-777

Gu S, Lundvall B-A (2006) Policy learning as a key process in the transformation of the Chinese innovation systems. In: Lundvall B-A, Intarakumnerd P, Vang J (eds) Asia's innovation systems in transition. Edward Elgar, Northampton, MA and Cheltenham

Heberer T (1991) Korruption in China: Analyse eines politischen, ökonomischen und sozialen Problems. Westdeutscher Verlag $\mathrm{GmbH}$, Opladen

Helfferich C (2009) Die Qualität qualitativer Daten: Manual für die Durchführung qualitativer Interviews, 3rd edn. VS Verlag fuer Sozialwissenschaften/Springer Fachmedien, Wiesbaden

Hillman B (2010) Factions and spoils: Examining political behavior within the local state in China. China J Number 64. Available at: https://crawford.anu.edu.au/pdf/staff/ben_hillman/2013/factions-and-spoils-china-journal.pdf. Accessed 25 Nov 2016

Irawati D, Gebhardt C (2013) Innovation policy as a concept for developing economies: Renewed perspectives on the Triple Helix system (Introduction to Special Issue). Ind High Educ 27(4):231-235

Jansen SA (2005) Elemente "positiver" und "dynamischer" Theorien der Korruption - Multidisziplinäre Provokationen zur Form der Korruption. In: Jansen SA, Briddat BP (eds) Korruption: Unaufgeklärter Kapitalismus - Multidisziplinäre Perspektiven zu Funktionen und Folgen der Korruption. VS Verlag für Sozialwissenschaften, Wiesbaden, pp 11-42

Kaufmann A, Toedtling T (2001) Science-industry interaction in the process of innovation: The importance of boundary-crossing between systems. Res Policy 30(5):791-804 
Klinkhammer J (2013) On the dark side of the code: Organizational challenges to an effective anti-corruption strategy. Crime Law Soc Chang 60(2):191-208

Kruse J (2015) Qualitative Interviewforschung: Ein Integrativer Ansatz, 2nd edn. Beltz Juventa, Basel

Lambsdorff J (2007) The institutional economics of corruption and reform: Theory, evidence and policy. Cambridge University Press, Cambridge

Lancaster T, Montinola G (2001) Comparative political corruption: Issues of operationalization and measurement. Springer, New York

Landry P (2008) Decentralized authoritarianism in China: The communist party's control of local elites in the post-Mao era. Cambridge University Press, New York

Lu X (2000) Booty socialism, bureau-preneurs, and the state in transition: Organizational corruption in China. Comparat Politics 32(3):273-294

Luhmann N (1964) Funktionen und Folgen formaler Organisation, 20th edn. Duncker \& Humblot, Berlin

Martin N (2015) Corruption in China., Invited Lecture, delivered at the Heidelberg Department of Sociology, Heidelberg University, Heidelberg, 03 July 2015

Martin N (2016) Media coverage, industrial policy and safety: Explaining shifting state and private ownership in China's coal-mining industry. Unpublished PhD Thesis, Political Science Department, MIT, Boston, MA

Mayntz R (1978) Soziologie der öffentlichen Verwaltung. C. F. Müller Juristischer Verlag, 1978

OECD (2010) Good practice guidance on internal controls, ethics and compliance. OECD, Paris, Available at: http:/www.oecd.org/investment/anti-bribery/anti-briberyconvention/44884389.pdf. Accessed 15 Sep 2015

Otter N, Weber M (2015) Determinants of public sector innovation: The example of capacity development in public procurement. Int Public Administr Rev 13(1):9-27

Palmer D (2012) Normal organizational wrongdoing: A critical analysis of theories of misconduct in and by organizations. Oxford University Press, Oxford

Pinto J, Leana CR, Pil FK (2008) Corrupt organizations or organizations of corrupt individuals? Two types of organization-level corruption. Acad Manag Rev 33(3):685-709

Pohlmann M (2008) Management und Moral. In: Blank T, Münch T, Sita Schanne S, Staffhorst C (eds) Integrierte Soziologie: Perspektiven zwischen Ökonomie und Soziologie, Praxis und Wissenschaft. Rainer Hampp, München und Mering, pp 161-176

Pohlmann M, Bitsch K, Klinkhammer J (2016) Personal gain or organizational benefits: How to explain active corruption? German Law J 17(1):73-100

Polishchuk L (2009) Corporate social responsibility or government regulation: An analysis of institutional choice. Prob Econ Transit 52(8):73-94

Redding GS (1993) The spirit of Chinese capitalism. De Gruyter, Berlin

Reindl A (2014) Der Beitrag der OECD zur Entwicklung von Corporate Compliance Standards. In: Bungenberg M, Dutzi A, Krebs P, Zimmermann N (eds) Corporate compliance and corporate social responsibility. Nomos, Baden-Baden, pp 127-145

Rohwer A (2009) Measuring corruption: A comparison between the transparency international's corruption perceptions index and the World Bank's worldwide governance indicators, CESifo DICE Report 3/2009. Available at: https://www.cesifo-group.de/portal/pls/portal/docs/1/1192926.PDF. Accessed 20 Sep 2015

Roth M (2014) Compliance - Die ungeteilte Verantwortung. In: Bungenberg M, Dutzi A, Krebs P, Zimmermann N (eds) Corporate compliance and corporate social responsibility. Nomos, Baden-Baden, pp 45-58

Ruth M (2002) Corruption and the energy sector, Management Systems International, USAID, (White Paper)., Available at: http://pdf.usaid.gov/pdf_docs/Pnact875.pdf. Accessed 23 May 2017

Saxenian A (2006) The new Argonauts: Regional advantage in a global economy. Harvard University Press, Cambridge, MA

Shapira P, Wang J (2010) Follow the money. Nature 7324(468):627-628

Smits RE, Kuhlmann S, Teubal M (2010) A system-evolutionary approach for innovation policy. In: Smits RE, Kuhlmann S, Shapira P (eds) The theory and practice of innovation policy: An international research handbook. Edward Elgar, Northampton, MA and Cheltenham, pp 417-448

Staffhorst C (2010) Wertkonflikte in Unternehmen Eine Erweiterte Organisationstheoretische Analyse Von Korruption. Verlag für Sozialwissenschaften, Wiesbaden

Suttmeier RP (1985) Corruption in science: The Chinese case. Sci Technol Hum Values 10(1):49-61

Tagscherer U, Kroll H, Luo X (2012) Regional innovation systems in China: An analysis of industry-science linkages in the Bohai Bay area. In: Petti C (ed) Technological entrepreneurship in China: How does it work? Edward Elgar, Northampton, MA and Cheltenham

Thun E (2004) Keeping up with the Jones': Decentralization, policy imitation and industrial development in China. World Dev 32(8):1289-1308

TII (Transparency International Index) (2015) Corruption statistics., Available at: https://www.transparency.org/news/ feature/corruption_perceptions_index_2016. Accessed 20 Sep 2015

Venard B (2009) Organizational isomorphism and corruption: An empirical research in Russia. J Bus Ethics 89(1):59-76

Wang P (2014) Extra-legal protection in China: How guanxi distorts China's legal system and facilitates the rise of unlawful protectors. Br J Criminol 54(5):809-830

Wang X, Woo WT (2011) The size and distribution of hidden household income in China. Asian Economic Papers No. 10:1

Weick KE (1995) Sensemaking in organizations. Sage, Thousand Oaks, CA

World Bank (1997) Helping countries combat corruption: The role of the World Bank., The World Bank, Available at: http://www1.worldbank.org/publicsector/anticorrupt/corruptn/corrptn.pdf, Accessed 28 Nov 2016

World Bank (2012) China 2030: Building a modern, harmonious and creative society., Available at: http://www. worldbank.org/content/dam/Worldbank/document/China-2030-complete.pdf. Accessed 28 Nov 2016

Yuanyuan L, Pohlmann M (2016) "Sturm der Antikorruption" in China. HeiGos Blog University of Heidelberg., Available at: https://www.soz.uni-heidelberg.de/?page_id=3833. Accessed 16 Nov 2016 
Zhou C (2008) Emergence of the entrepreneurial university in evolution of the Triple Helix: The case of Northeastern University in China. J Technol Manage China 3(1):109-126

Zhou C (2014) Four dimensions to observe a Triple Helix: Invention of 'cored model' and differentiation of institutional and functional spheres. Triple Helix 1(1):Article 11

Zhou C, Etzkowitz H (2012) Asian Triple Helix: Evolution of the university's role. In: Douglas J, editor. China futurisms: Research universities and leaders or followers? [translated into Chinese and published by University Education Science, Hunan University, May 2014]; Social Research: An International Quarterly 79(3):639-688.

Submit your manuscript to a SpringerOpen ${ }^{\circ}$ journal and benefit from:

- Convenient online submission

- Rigorous peer review

- Open access: articles freely available online

- High visibility within the field

- Retaining the copyright to your article

Submit your next manuscript at $>$ springeropen.com 